\title{
Simultaneous RP-HPLC determination of sparfloxacin and dexamethasone in pharmaceutical formulations
}

\author{
Syed Naeem Razzaq ${ }^{1}$, Muhammad Ashfaq ${ }^{2, *}$, Irfana Mariam³, Islam Ullah Khan', \\ Syed Saleem Razzaq ${ }^{4}$
}

\begin{abstract}
${ }^{1}$ Department of Chemistry, Government College University, Lahore, Pakistan, ${ }^{2}$ Department of Chemistry, University of Gujrat, Gujrat, Pakistan, ${ }^{3}$ Department of Chemistry, Queen Marry College, Lahore, Pakistan, ${ }^{4}$ Quality Control Department, HPLC

Section, Bayer Pakistan Pvt. Ltd, Lahore, Pakistan
\end{abstract}

\begin{abstract}
The present study describes the development and subsequent validation of simple and accurate stability indicating RP-HPLC method for the determination of sparfloxacin and dexamethasone in pharmaceutical formulations in the presence of their stress-induced degradation products. Both the drugs and their stress-induced degradation products were separated within 10 minutes using C8 column and mixture of methanol and $0.02 \mathrm{M}$ phosphate buffer $\mathrm{pH} 3.0(60: 40 \mathrm{v} / \mathrm{v}$, respectively) as mobile phase at $270 \mathrm{~nm}$ using diode array detector. Regression analysis showed linearity in the range of $15-105 \mu \mathrm{g} / \mathrm{mL}$ for sparfloxacin and $5-35 \mu \mathrm{g} / \mathrm{mL}$ for dexamethasone. All the analytes were adequately resolved with acceptable tailing. Peak purity of the two drugs was also greater than 0.9999 , showing no co-elution peaks. The developed method was applied for simultaneous determination of sparfloxacin and dexamethasone in pharmaceutical formulations for stability studies.
\end{abstract}

Uniterms: RP-HPLC. Sparfloxacin. Dexamethasone. Degradation products. Stability studies.

O presente estudo descreve o desenvolvimento e a subsequente validação de indicador de estabilidade simples e acurada por RP-HPLC para a determinação de esparfloxacino e dexametasona em formulações farmacêuticas na presença de produtos de degradação induzidos por estresse. Tanto os fármacos quanto os produtos de degradação induzidos pelo estresse foram separados em 10 minutos, utilizando coluna C8 e mistura de methanol e tampão fosfato $0,02 \mathrm{M}, \mathrm{pH} 3,0(60: 40 \mathrm{v} / \mathrm{v}$, respectivamente) como fase móvel e detector de arranjo de diodo a $270 \mathrm{~nm}$, A análise de regressão mostrou linearidade na faixa de 15-105 $\mu \mathrm{g} / \mathrm{mL}$ para esparfloxacino e 5-35 $\mu \mathrm{g} / \mathrm{mL}$ para a dexametsona. Todos os analitos foram resolvidos adequadamente com tailing aceitável. O pico de pureza dos dois foi maior que 0.9999 , não mostrando picos de co-eluição. O método desenvolvido foi aplicado para a determinação simultânea de esparfloxacino e dexametasona em formulações farmacêuticas e para estudos de estabilidade.

Unitermos: RP-HPLC. Esparfloxacino. Dexametasona. Produtos de degradação. Estudos de estabilidade.

\section{INTRODUCTION}

ICH and WHO recommended that analysis of pharmaceutical finished products during stability testing should be conducted by use of a validated stability-indicating method. In this study ICH and WHO recommendations were therefore kept in mind for the simultaneous determination of sparfloxacin and dexamethasone.

*Correspondence: Md. Ashfaq. Department of Chemistry, University of Gujrat, H.H. Campus, Gujrat-50700, Pakistan. E-mail: m.ashfaq@uog.edu.pk
Sparfloxacin is chemically designated as 5-amino1-cyclopropyl-7-(cis-3,5-dimethyl-1-piperazinyl)-6,8difluoro-1,4-dihydro-4-oxo-3-quinolinecarboxylic acid (Figure 1). It is a broad spectrum antibiotic and is used for the treatment of bacterial corneal infections, bacterial conjunctivitis and corneal ulcer to control the infections of the eye (Reynolds, 2009). Dexamethasone (Figure 1) chemically designated as $(8 S, 9 R, 10 S, 11 S, 13 S, 14 S, 16 R, 17 R)$-9-fluoro-11,17dihydroxy-17-(2-hydroxyacetyl)-10,13,16-trimethyl$6,7,8,9,10,11,12,13,14,15,16,17$-dodecahydro- $3 H$ cyclopenta $[a]$ phenanthren-3-one is a corticosteroid, used 
primarily for inflammatory ocular conditions (Reynolds, 2009). Individually sparfloxacin and dexamethasone have been analysed by various techniques. The techniques used for sparfloxacin include HPLC (Marona, Schapoval, 1999, 2001; Marona, Zuanazzi, Schapoval, 1999; Salgado et al., 2005; Al-Sayed, 1995), HPTLC (Mody et al., 1998), UV/VIS (Marona, Schapoval, 1999, 2001) and LC-MS (Noh et al., 2010). The analytical methods existed for dexamethasone include determination by HPLC (Iqbal et al., 2006; Huetos et al., 1999; Mallinson et al., 1995; Chen et al., 2008; Gallegos, Arroyo, 2002; Urban, Mainardes, Gremiao, 2009; Kwak, D’Amico, 1995), GC-MS (Mallinson et al., 1995) and thin layer chromatography (Huetos et al., 1999).
(A)

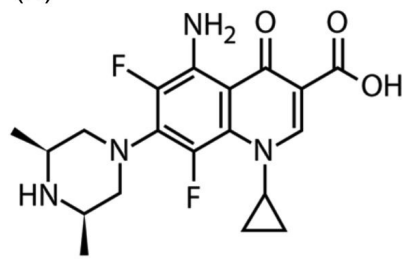

(B)

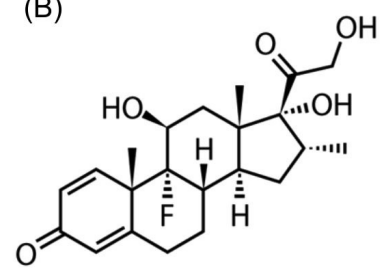

FIGURE 1 - Chemical structures of sparfloxacin (A) and dexamethasone (B).

The combination of sparfloxacin and dexamethasone has not been adopted by any official pharmacopoeia. An extensive review of the literature did not reveal any stability indicating HPLC method (with forced degradation studies) for simultaneous determination of both drugs. Therefore attempts were made to develop and validate simple and precise stability indicating RPHPLC method for simultaneous determination of both drugs and their stress induced degradation products in pharmaceutical formulations. We are currently engaged in developing new HPLC methods for different classes of drugs in binary combination either in pharmaceutical formulations or in human plasma (Qutab et al., 2007a,b, 2009; Ashfaq et al., 2007; Ashfaq, Khan, Asghar, 2008; Khan et al., 2008, 2010, 2012; Khan, Jilani, Ashfaq, 2010; Sharif et al., 2010.; Razzaq et al., 2012a,b,c,d). The present research work is a continuation of the work we have already reported.

\section{MATERIAL AND METHODS}

\section{Chemicals and Reagents}

Pure Reference standards (secondary standards) of sparfloxacin and dexamethasone with declared purity of 99.50 and $99.96 \%$ respectively were obtained from Schazoo
Zaka Laboratories (Lahore, Pakistan). Spar-D eye drops (Biomedica International) claimed to contain $3 \mu \mathrm{g} / \mathrm{mL}$ of sparfloxacin and $1 \mu \mathrm{g} / \mathrm{mL}$ of dexamethasone (base) were used in this study. Methanol was of HPLC grade, whereas all other chemicals and reagents used in this study were of analytical reagent grade and were procured from M.S Traders Lahore, Pakistan (Fluka origin). Double distilled water was used for all the experiments. Filtration of the mobile phase was done using $0.45 \mu \mathrm{m}$ nylon filters (Millipore, USA).

\section{Equipment and chromatographic conditions}

The HPLC system consisted of Shimadzu LC-20A system (Kyoto, Japan) equipped with model LC-20AT pump, SPD-M20A Diode array detector (set at $270 \mathrm{~nm}$ ), and DGU-20A5 online degasser, and a Rheodyne injection valve with a $20 \mu \mathrm{L}$ loop. Peak areas were integrated using a Shimadzu LC solution (version 1.227) software program. Experimental conditions were optimized on a Hypersil C 8 column $(250$ X $4.6 \mathrm{~mm}, 5 \mu \mathrm{m})$ at room temperature. Mobile phase was prepared by mixing $0.02 \mathrm{M}$ phosphate buffer and methanol in ratio of 40:60 v/v, respectively. Phosphate buffer was prepared by dissolving $2.72 \mathrm{~g}$ of potassium dihydrogen phosphate in $1000 \mathrm{~mL}$ of water. Its $\mathrm{pH}$ was adjusted to 3.0 with phosphoric acid after the addition of $1 \mathrm{~mL}$ of triethylamine. Mobile phase was flowed at $1.5 \mathrm{~mL} / \mathrm{min}$ and all chromatographic experiments were performed at room temperature $\left(25^{\circ} \mathrm{C} \pm 2{ }^{\circ} \mathrm{C}\right)$.

\section{Preparation of standard solution}

Standard stock solution of the two drugs was prepared by accurately weighing $37.5 \mathrm{mg}$ sparfloxacin and $12.5 \mathrm{mg}$ dexamethasone and then dissolved in few $\mathrm{mL}$ of methanol. The volume of this solution was then marked to $25 \mathrm{~mL}$ with $0.1 \mathrm{M}$ sodium hydroxide and sonicated for 10 minutes. To prepare working standard solution, $1 \mathrm{~mL}$ of the above solution was diluted to $25 \mathrm{~mL}$ with mobile phase. The solution so obtained has concentration equal to $60 \mu \mathrm{g} / \mathrm{mL}$ sparfloxacin and $20 \mu \mathrm{g} / \mathrm{mL}$ dexamethasone. The solution was filtered using nylon filter before analysis.

\section{Preparation of sample solution}

$1 \mathrm{~mL}$ commercial eye drop was diluted to $50 \mathrm{~mL}$ with mobile phase to obtain concentration equal to $60 \mu \mathrm{g} / \mathrm{mL}$ sparfloxacin and $20 \mu \mathrm{g} / \mathrm{mL}$ dexamethasone. The solution was filtered using nylon filter before analysis. 


\section{Linearity}

Linear calibration plots of the proposed method were obtained over concentration ranges of $15-105 \mu \mathrm{g} / \mathrm{mL}(15$, $30,45,60,75,90$ and $105 \mu \mathrm{g} / \mathrm{mL}$ ) for sparfloxacin and $5-35 \mu \mathrm{g} / \mathrm{mL}$ dexamethasone $(5,10,15,20,25,30$ and 35 $\mu \mathrm{g} / \mathrm{mL})$. Triplicate analysis of each solution was carried out.

\section{Accuracy}

To demonstrate the accuracy of the proposed method, standard addition method was used. For this purpose, known quantities of sparfloxacin and dexamethasone were supplemented to the sample solution previously analysed. The results of this solution were compared with the true results. Three levels of solutions in the range of $50-150 \%$ of nominal analytical concentration $(60 \mu \mathrm{g} / \mathrm{mL}$ sparfloxacin and $20 \mu \mathrm{g} / \mathrm{mL}$ dexamethasone) were prepared and analyzed.

\section{Precision}

Intra-day and inter-day precision was calculated to perform precision. Intra-day precision was measured by analyzing three different concentrations five times within the same day and inter-day precision were determined by evaluating the response of same solutions for three days. RSD of the peak area was then calculated.

\section{Specificity (Stress Testing)}

For specificity demonstration, acidic, basic, oxidative, thermal and photolytic stresses were applied as described by ICH in its guidelines. All stress studies were performed in $25 \mathrm{~mL}$ volumetric flask.

\section{Acid Degradation Studies}

Acid degradation study was performed in versatile environmental test chamber (Sanyo, Japan) at $40{ }^{\circ} \mathrm{C} / 75 \%$ $\mathrm{RH}$ using $5 \mathrm{M} \mathrm{HCl}$. For this purpose, $1 \mathrm{~mL}$ of the standard stock solution and $1 \mathrm{~mL}$ of $5 \mathrm{M} \mathrm{HCl}$ were taken in $25 \mathrm{~mL}$ volumetric flask and then kept in versatile environmental test chamber at $40{ }^{\circ} \mathrm{C} / 75 \% \mathrm{RH}$. After 22 hours, those solutions were neutralized using $5 \mathrm{M}$ sodium hydroxide and finally completed till the mark with mobile phase.

\section{Base Degradation Studies}

Base degradation study was performed in versatile environmental test chamber (Sanyo, Japan) at $40{ }^{\circ} \mathrm{C} / 75 \%$ $\mathrm{RH}$ and at $22{ }^{\circ} \mathrm{C} / 49 \% \mathrm{RH}$ using $5 \mathrm{M} \mathrm{NaOH}$. For this purpose, $1 \mathrm{~mL}$ of the standard stock solution and $1 \mathrm{~mL}$ of $5 \mathrm{M} \mathrm{NaOH}$ were taken in $25 \mathrm{~mL}$ volumetric flask and then kept in versatile environmental test chamber at $40{ }^{\circ} \mathrm{C} / 75 \% \mathrm{RH}$ for $16 \mathrm{~h}$ and at $22{ }^{\circ} \mathrm{C} / 49 \% \mathrm{RH}$ for forty five minutes. After the stated times, the solutions were neutralized using $5 \mathrm{M} \mathrm{HCl}$ and completed till the mark with mobile phase.

\section{Oxidative Degradation Studies}

Oxidative degradation study was performed in versatile environmental test chamber (Sanyo, Japan) at $40{ }^{\circ} \mathrm{C} / 75 \% \mathrm{RH}$ using $6 \% \mathrm{H}_{2} \mathrm{O}_{2}$. For this purpose, $1 \mathrm{~mL}$ of the standard stock solution and $1 \mathrm{~mL}$ of $6 \% \mathrm{H}_{2} \mathrm{O}_{2}$ were taken in $25 \mathrm{~mL}$ volumetric flasks and then kept in versatile environmental test chamber at $40{ }^{\circ} \mathrm{C} / 75 \% \mathrm{RH}$ for $22 \mathrm{~h}$. After completion of the stress, the flask was completed till the mark with mobile phase.

\section{Thermal Degradation Studies}

Thermal degradation study was performed in versatile environmental test chamber (Sanyo, Japan) at $40{ }^{\circ} \mathrm{C} / 75 \% \mathrm{RH}$. For this purpose, $1 \mathrm{~mL}$ of the standard stock solution in $25 \mathrm{~mL}$ volumetric flask was kept in versatile environmental test chamber at $40{ }^{\circ} \mathrm{C} / 75 \% \mathrm{RH}$ for $22 \mathrm{~h}$. After completion of the stress, the $25 \mathrm{~mL}$ flask was completed till the mark with mobile phase.

\section{Photolytic Degradation Studies}

For photolytic degradation study, $1 \mathrm{~mL}$ of the standard stock solution in $25 \mathrm{~mL}$ volumetric flask was placed in the direct sunlight. After $1.25 \mathrm{~h}$, the flask was completed with mobile phase till the mark.

\section{Robustness}

Premeditate variations were performed in the experimental conditions of the proposed method to assess the method robustness. For this, faint modifications were made in the operating conditions like mobile phase composition, flow rate and $\mathrm{pH}$ of buffer solution. The effect of these changes on chromatographic results was then measured.

\section{RESULTS AND DISCUSSION}

In this study, we developed a simple, sensitive and accurate RP-HPLC method for the separation of sparfloxacin and dexamethasone and their stress induced degradation products using $\mathrm{C} 8$ column. In order to obtain symmetrical peaks with better resolution, the chromatographic conditions i.e. $\mathrm{pH}$ of the buffer, concentration of organic modifier and flow rate of the 
mobile phase were optimized. During first phase of this method development both methanol and acetonitrile were tried as organic content of the mobile phase along with phosphate buffer ( $\mathrm{pH} 3.0 ; 20 \mathrm{mM})$ in order to get the peaks with better selectivity and good resolution. Use of acetonitrile resulted in broader peaks, whereas better peaks were obtained using methanol. Increase in temperature of the column oven from 30 to $50{ }^{\circ} \mathrm{C}$ did not improve the peak shapes of the analytes during acetonitrile use. So finally methanol was selected as organic portion of the mobile phase.

For selection of the buffer, phosphate buffer $(\mathrm{pH}$ $3.0 ; 0.02 \mathrm{M}$ ) was taken because some researchers have used acid medium for the separation of corticosteroids and quinolones (Schil, Charles, 1994).

Hydrogen ion concentration has a definite control on the retention properties of substances so its influence on the separation efficiency of sparfloxacin and dexamethasone was studied. Different phosphate buffer solutions of the same strength but different $\mathrm{pH}(3,4,5,6$ and 7$)$ were prepared to check the separation efficiency under different acidic conditions. The use of buffers of different $\mathrm{pH}$ did not result in change in retention times of the analytes but results in peaks with variable asymmetry. In all those conditions except at $\mathrm{pH} 3$, there was considerable peak tailing for sparfloxacin, so $\mathrm{pH} 3$ was finally selected for further studies.

The percentage of methanol in the mobile phase was varied from 40 to $80 \%$ in order to check the effect of organic modifier on the separation efficiency of the two analytes. Obviously, in RP-chromatography decreasing the polarity of the mobile phase results in faster elution so increasing concentration of methanol decreased the retention time of the analytes. Peaks with maximum selectivity and with all the chromatographic parameters within acceptable range were observed when using $60 \%$ methanol and $40 \%$ buffer within eight minutes as can be seen in Figure 2.

ICH guidelines were kept in practice for validation of the method (ICH,1996). Validation parameters performed include linearity, accuracy, precision, robustness, specificity, detection limit and quantitation limit.

Linear calibration plots for the proposed method were obtained in concentration ranges of $15-105 \mu \mathrm{g} / \mathrm{mL}$ $(15,30,45,60,75,90$ and $105 \mu \mathrm{g} / \mathrm{mL})$ for sparfloxacin and $5-35 \mu \mathrm{g} / \mathrm{mL}$ dexamethasone $(5,10,15,20,25,30$ and $35 \mu \mathrm{g} / \mathrm{mL})$. The linear regression equation for sparfloxacin was found to be $\mathrm{Y}=51523 \mathrm{X}+7651$ with correlation coefficient equal to 0.999 whereas for dexamethasone, it was $\mathrm{Y}=81718 \mathrm{X}+2313$ with correlation coefficient equal to 0.999 .

The detection limit (DL) and quantitation limit (QL) were determined by making different solution with decreasing concentrations. DL was found to be $0.45 \mu \mathrm{g} / \mathrm{mL}$ and $0.15 \mu \mathrm{g} / \mathrm{mL}$ for sparfloxacin and dexamethasone, respectively (S/N ratio 3:1). QL was found to be $1.36 \mu \mathrm{g} / \mathrm{mL}$ and $0.45 \mu \mathrm{g} / \mathrm{mL}$ for sparfloxacin and dexamethasone, respectively ( $\mathrm{S} / \mathrm{N}$ ratio 10:1).

Accuracy of the method was performed by the standard addition technique. Three levels of solutions (50,

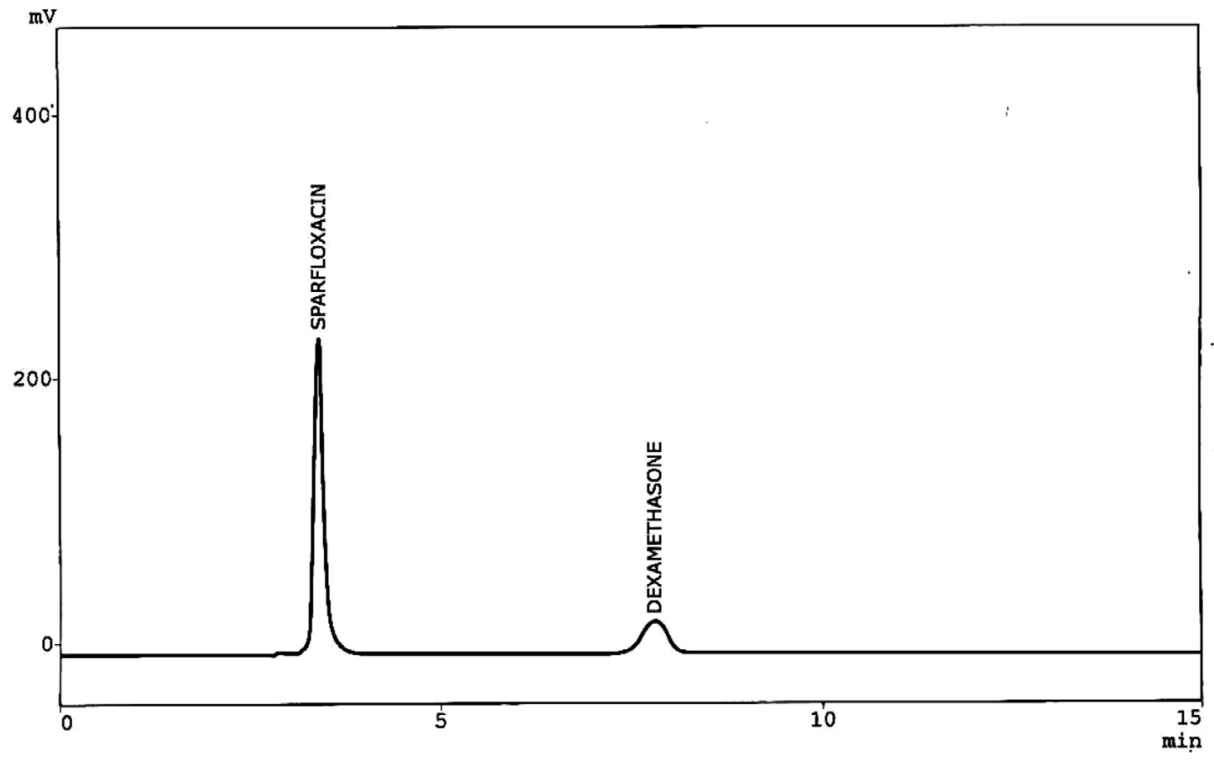

FIGURE 2 - Chromatogram of sparfloxacin $\left(t_{R}=3.415\right)$ and dexamethasone $\left(t_{R}=7.792\right)$ in pharmaceutical formulations. Chromatographic conditions: mobile phase methanol: $0.02 \mathrm{M}$ phosphate buffer (60:40, v/v), pH 3.0, Column BDS Hypersil C8 $(250 \mathrm{X} 4.6,5 \mu \mathrm{m})$, flow rate $1.5 \mathrm{~mL} \mathrm{~min}^{-1}$, injection volume $20 \mu \mathrm{L}$, wavelength $270 \mathrm{~nm}$. Concentration: $60 \mu \mathrm{g} / \mathrm{mL}$ sparfloxacin and $20 \mu \mathrm{g} / \mathrm{mL}$ dexamethasone. 
100 and $150 \%$ ) of the nominal analytical concentrations were prepared. Percentage recoveries along with standard deviation and relative standard deviations for each analyte $(n=5)$ are given in (Table I). Recovery studies showed the method to be highly accurate and suitable for intended use.

Intra-day and inter-day precision was calculated to perform precision. Intra-day precision was measured by analyzing three different concentrations five times within the same day and inter-day precision were determined by evaluating the response of same solutions for three days. Relative standard deviation (RSD \%) of the peak area was calculated to represent precision. The results of intra-day and inter-day precision are presented in (Table II).

Robustness of the method was performed by slightly varying the chromatographic conditions. The results showed negligible effect on the chromatographic parameters by slight variations in chromatographic conditions (Table III and Table IV).

Specificity of the developed method was evaluated by applying different stress conditions (acid, base, oxidation, thermal and photolytic) to sparfloxacin and dexamethasone in combination form. The chromatograms
TABLE I - Accuracy of the Proposed HPLC Method

\begin{tabular}{lcc}
\hline Drugs & $\begin{array}{c}\text { Spiked } \\
\text { concentration* } \\
(\mu \mathrm{g} / \mathrm{mL})\end{array}$ & $\begin{array}{c}\text { Measured } \\
\text { concentration* } \\
(\mu \mathrm{g} / \mathrm{mL}) \pm \mathrm{SD} ; \\
\mathrm{RSD}(\%)\end{array}$ \\
\hline Sparfloxacin & 30.0 & $29.8 \pm 0.7 ; 0.1$ \\
& 60.0 & $60.1 \pm 0.4 ; 0.7$ \\
\hline Dexamethasone & 90.0 & $91.4 \pm 0.5 ; 1.0$ \\
\hline & 10.0 & $10.0 \pm 0.2 ; 0.4$ \\
& 20.0 & $20.1 \pm 0.9 ; 0.5$ \\
\hline
\end{tabular}

$*=$ Average of 5 analysis

under different stress conditions are shown in (Figure 3). The results of stress studies are given in (Table V).

All the stress conditions applied were enough to degrade both the drugs. Comparison of the two drugs showed that sparfloxacin is more stable as compared to dexamethasone. Under acidic conditions dexamethasone was degraded up to $97.3 \%$ and sparfloxacin was degraded up to 93.7. Under basic stress dexamethasone was

TABLE II - Intra-Day and Inter-Day Precision of the Proposed HPLC Method

\begin{tabular}{lccc}
\hline Drugs & $\begin{array}{c}\text { Actual Concentration } \\
(\mu \mathrm{g} / \mathrm{mL})\end{array}$ & $\begin{array}{c}\text { Intra-day Precision } \\
\text { Measured conc.; } \pm \text { SD; RSD }(\%)\end{array}$ & $\begin{array}{c}\text { Inter-day precision } \\
\text { Measured conc.; } \pm \text { SD; RSD (\%) }\end{array}$ \\
\hline Sparfloxacin & 30.0 & $30.2 \pm 0.4 ; 1.1$ & $29.6 \pm 0.7 ; 1.2$ \\
& 60.0 & $60.7 \pm 0.8 ; 0.1$ & $59.8 \pm 0.8 ; 0.7$ \\
\hline Dexamethasone & 90.0 & $90.1 \pm 0.4 ; 1.5$ & $89.8 \pm 1.2 ; 1.1$ \\
& 10.0 & $10.0 \pm 0.1 ; 0.4$ & $10.0 \pm 0.2 ; 0.3$ \\
& 20.0 & $19.9 \pm 0.2 ; 0.8$ & $20.2 \pm 0.5 ; 0.4$ \\
& 30.0 & $29.9 \pm 0.5 ; 1.0$ & $30.0 \pm 0.5 ; 0.1$ \\
\hline
\end{tabular}

TABLE III - Robustness study of sparfloxacin

\begin{tabular}{lcccc}
\hline Chromatographic Conditions & Assay $\%$ & $\mathrm{t}_{\mathrm{R}}(\mathrm{min})$ & Theoretical plates & Tailing \\
\hline Methanol:buffer (63:37) & 100.1 & 3.221 & 4307 & 1.34 \\
Methanol:buffer (60:40) & 99.6 & 3.415 & 4358 & 1.34 \\
Methanol:buffer (57:43) & 101.5 & 3.515 & 4358 & 1.31 \\
Flow rate (1.3 mL/min) & 101.4 & 3.625 & 4398 & 1.32 \\
Flow rate (1.5 mL/min) & 100.8 & 3.415 & 4387 & 1.34 \\
Flow rate (1.7 mL/min) & 101.8 & 3.199 & 4325 & 1.34 \\
Buffer (pH 2.8) & 102.0 & 3.411 & 4358 & 1.32 \\
Buffer (pH 3.0) & 101.4 & 3.417 & 4322 & 1.34 \\
Buffer (pH 3.2) & 100.2 & 3.417 & 4378 & 1.34 \\
\hline
\end{tabular}


TABLE IV - Robustness study of dexamethasone

\begin{tabular}{lcccc}
\hline Chromatographic Conditions & Assay $\%$ & $\mathrm{t}_{\mathrm{R}}(\mathrm{min})$ & Theoretical plates & Tailing \\
\hline Methanol:buffer (63:37) & 100.4 & 7.214 & 2021 & 1.04 \\
Methanol:buffer (60:40) & 101.2 & 7.792 & 2074 & 1.04 \\
Methanol:buffer (57:43) & 102.0 & 8.311 & 2144 & 1.10 \\
Flow rate (1.3 mL/min) & 99.1 & 8.333 & 2254 & 1.10 \\
Flow rate (1.5 mL/min) & 99.5 & 7.792 & 2047 & 1.02 \\
Flow rate (1.7 mL/min) & 100.5 & 7.169 & 2178 & 1.03 \\
Buffer (pH 2.8) & 101.6 & 7.697 & 2298 & 1.02 \\
Buffer (pH 3.0) & 100.7 & 7.792 & 2258 & 1.04 \\
Buffer (pH 3.2) & 100.2 & 7.798 & 2241 & 1.10 \\
\hline
\end{tabular}

TABLE V - Stress Testing Results of sparfloxacin and dexamethasone

\begin{tabular}{|c|c|c|c|c|c|}
\hline \multirow{2}{*}{$\begin{array}{l}\text { Nature } \\
\text { of stress }\end{array}$} & \multirow{2}{*}{$\begin{array}{c}\text { Storage } \\
\text { Conditions }\end{array}$} & \multirow{2}{*}{$\begin{array}{l}\text { Time } \\
\text { (h) }\end{array}$} & Amount of sparfloxacin & Amount of dexamethasone & \multirow{2}{*}{$\begin{array}{c}\text { Extent of } \\
\text { decomposition }\end{array}$} \\
\hline & & & Remaining \pm RSD (\%) & Remaining \pm RSD (\%) & \\
\hline $5 \mathrm{M} \mathrm{HCl}$ & $\left(40^{\circ} \mathrm{C} / 75 \% \mathrm{RH}\right)$ & 22 & $6.3 \pm 2.5(\mathbf{P P I}=\mathbf{1 . 0 0 0 0})$ & $2.7 \pm 2.3(\mathbf{P P I}=\mathbf{1 . 0 0 0 0})$ & Substantial \\
\hline \multirow[t]{2}{*}{$5 \mathrm{M} \mathrm{NaOH}$} & $\left(22^{\circ} \mathrm{C} / 49 \% \mathrm{RH}\right)$ & 0.75 & $91.2 \pm 1.4(\mathbf{P P I}=\mathbf{1 . 0 0 0 0})$ & $6.0 \pm 2.1(\mathbf{P P I}=\mathbf{1 . 0 0 0 0})$ & Substantial \\
\hline & $\left(40^{\circ} \mathrm{C} / 75 \% \mathrm{RH}\right)$ & 16 & $8.04 \pm 1.4(\mathbf{P P I}=\mathbf{1 . 0 0 0 0})$ & $4.0 \pm 3.1(\mathbf{P P I}=\mathbf{1 . 0 0 0 0})$ & Substantial \\
\hline $6 \% \mathrm{H}_{2} \mathrm{O}_{2}$ & $\left(40^{\circ} \mathrm{C} / 75 \% \mathrm{RH}\right)$ & 22 & $5.5 \pm 1.0(\mathbf{P P I}=\mathbf{1 . 0 0 0 0})$ & $4.0 \pm 1.1(\mathbf{P P I}=\mathbf{1 . 0 0 0 0})$ & Substantial \\
\hline Thermal & $\left(40{ }^{\circ} \mathrm{C} / 75 \% \mathrm{RH}\right)$ & 22 & $4.1 \pm 1.3$ (PPI=1.0000) & $3.6 \pm 1.5$ (PPI=1.0000) & Substantial \\
\hline Photolytic & Sunlight & 1.25 & $98.7 \pm 1.2(\mathbf{P P I}=\mathbf{1 . 0 0 0 0})$ & $3.0 \pm 2.4(\mathbf{P P I}=\mathbf{1 . 0 0 0 0})$ & Substantial \\
\hline
\end{tabular}

PPI= Peak Purity Index

degraded up to $96 \%$ and sparfloxacin was degraded up to $91.9 \%$. Under oxidative stress dexamethasone was degraded up to $96 \%$ and sparfloxacin was degraded up to $94.5 \%$. Under thermal stress dexamethasone was degraded up to $96.4 \%$ and sparfloxacin was degraded up to $95.9 \%$. Under photolytic stress conditions dexamethasone was degraded up to $97.0 \%$ and sparfloxacin was found to be stable under photolytic stress. From these stress studies it was concluded that dexamethasone and sparfloxacin are not stable in basic, acidic, thermal, oxidative and photolytic stress conditions. The degradation pattern of the drugs is very similar under basic and photolytic stress conditions.

In addition to the percentage degradation of each drug, a number of degradation products (impurities) were produced under acidic, basic, thermal, oxidative and photolytic stress conditions (Figure 3). Application of the proposed method was checked by analyzing the sparfloxacin and dexamethasone in commercially available pharmaceutical products. The results are provided in (Table VI) which showed high percentage recoveries and low RSD (\%) values for both analytes.
TABLE VI - Assay results of sparfloxacin and dexamethasone in commercial eye drops

\begin{tabular}{lccc}
\hline $\begin{array}{l}\text { Products } \\
\text { Eye drops }\end{array}$ & Ingredient & $\begin{array}{c}\text { Label value } \\
(\mathrm{mg} / \mathrm{mL})\end{array}$ & $\begin{array}{c}\% \text { Recovery* } \\
\pm \mathrm{RSD}(\%)\end{array}$ \\
\hline Spar-D & Sparfloxacin & 3 & $100.3 \pm 0.3$ \\
& Dexamethasone & 1 & $99.0 \pm 0.7$ \\
\hline
\end{tabular}

$*=$ Average of 10 determination

\section{CONCLUSION}

A simple, sensitive, isocratic and accurate reverse phase HPLC method is described for simultaneous determination of sparfloxacin and dexamethasone in pharmaceutical formulations. The proposed method was validated by testing its linearity, accuracy, precision, limits of detection and quantitation and specificity. The method was good enough to separate the peaks of active pharmaceutical ingredients (APIs) from the degradation products (produced during forced degradation studies). It is also clear from the chromatograms that both the active 


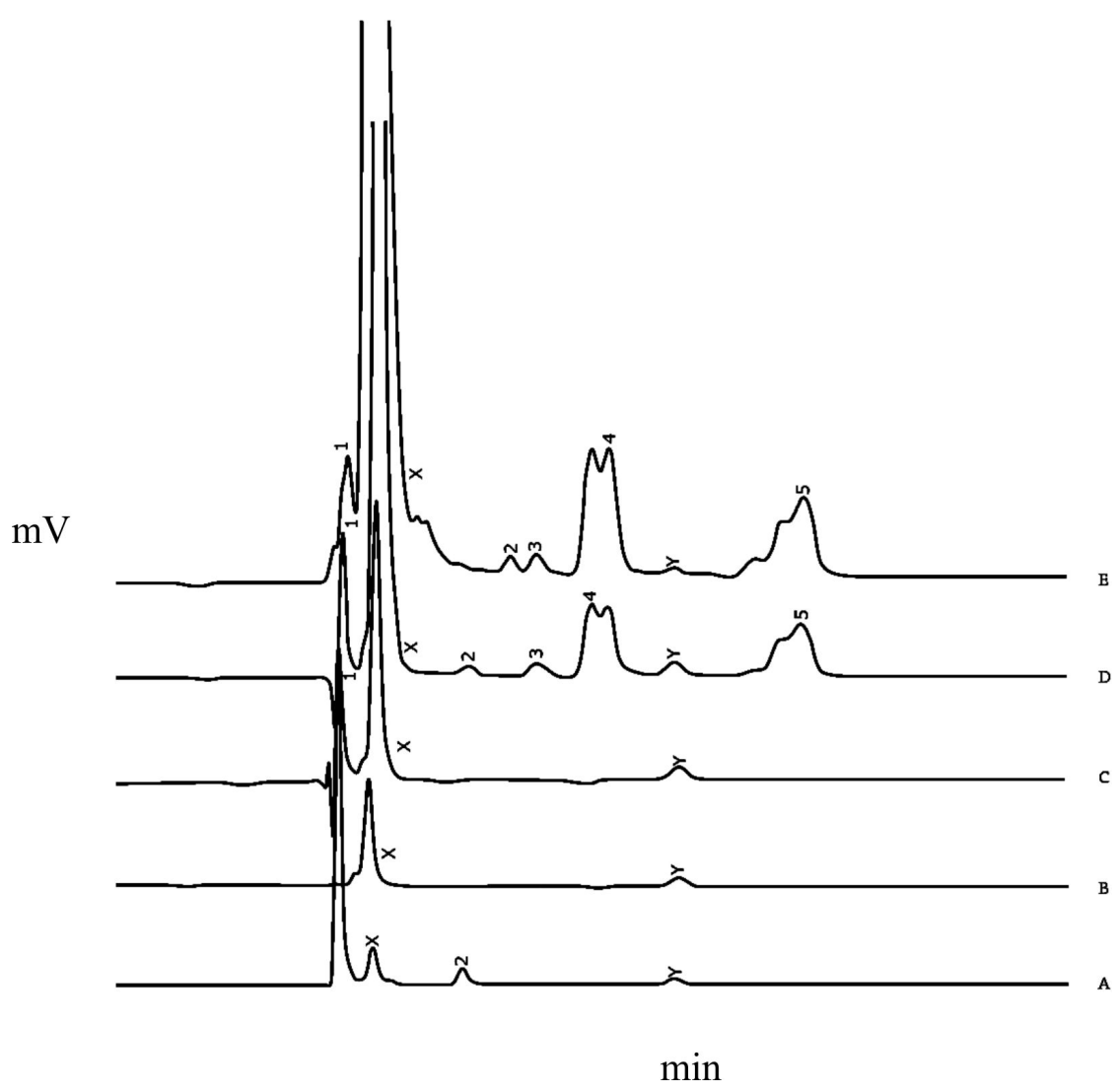

FIGURE - 3 A typical chromatogram of sparfloxacin $\left(t_{R}=3.425\right)$ and dexamethasone $\left(t_{R}=7.794\right)$ under acidic, basic, thermal, photolytic and oxidative stress conditions. Where $(\mathrm{X})$ is sparfloxacin peak, $(\mathrm{Y})$ dexamethasone peak, $(1,2,3,4$, and 5) degradation/ impurities peaks, (A) chromatogram of oxidative stress, (B) chromatogram of thermal stress, (C) chromatogram of acidic stress, (D) chromatogram of basic stress and (E) chromatogram of photolytic stress. Chromatographic conditions: mobile phase methanol: $0.02 \mathrm{M}$ phosphate buffer (60:40, v/v), pH 3.0, Column BDS Hypersil C8 (250 X 4.6, $5 \mu \mathrm{m})$, flow rate $1.5 \mathrm{~mL} \mathrm{~min}^{-1}$, injection volume $20 \mu \mathrm{L}$, wavelength $270 \mathrm{~nm}$.

ingredient peaks in all the stress conditions are free from any sort of degradation impurities. All these convince us to conclude that the method can be successfully used for any sort of stability and validation studies.

\section{REFERENCES}

AL-SAYED, Y.M. A simple high performance liquid chromatography assay of sparfloxacin in human serum. Anal. Lett., v.28, p.279-293, 1995.

ASHFAQ, M.; KHAN, I.U.; QUTAB, S.S.; RAZZAQ, S.N. HPLC determination of ezetimibe and simvastatin in pharmaceutical formulations. J. Chil. Chem. Soc., v.52, p.1220-1203, 2007.

ASHFAQ, M.; KHAN, I.U.; ASGHAR, M.N. Development and validation of liquid chromatographic method for gemfibrozil and simvastatin in binary combination. J. Chil. Chem. Soc., v.53, p.1617-1619, 2008.
CHEN, Q.; ZIELINSKI, D.; CHEN, J.; KOSKI, A.; WERST, D.; NOWAK, S. A validated, stability-indicating HPLC method for the determination of dexamethasone related substances on dexamethasone-coated drug-eluting stents. J. Pharm. Biomed. Anal., v.48, p.732-738, 2008.

GALLEGOS, J.M.L.; ARROYO, J.P. Simultaneous determination of dexamethasone and trimethoprim by liquid chromatography. J. Pharm. Biomed. Anal., v.30, p.1255-1261, 2002.

HUETOS, O.; RAMOS, M.; MARTÍN DE POZUELO, M.; SAN ANDRÉS, M.; REUVERS, T.B. Determination of dexamethasone in feed by TLC and HPLC. Analyst, v.124, p.1583-1587, 1999.

INTERNATIONAL CONFERENCE ON HARMONIZATION (Q2B). Note for guidance on validation of analytical procedures: methodology. Geneva: IFPMA, 1996. p.6-13 
IQBAL, M.S.; SHAD, M.A.; ASHRAF, M.W.; BILAL, M.; SAEED. M. Development and validation of an HPLC method for the determination of dexamethasone, dexamethasone sodium phosphate and chloramphenicol in presence of each other in pharmaceutical preparations. Chromatographia, v.64, p.219-222, 2006.

KHAN, I.U.; SHARIF, S.; ASHFAQ, M.; ASGHAR. M.N. Simultaneous determination of potassium clavulanate and cefixime in synthetic mixtures by high performance liquid chromatography. J. AOAC Int., v.91, p.744-749, 2008.

KHAN, I.U.; JILLANI, S.M.S.; ASHFAQ, M. Determination of atorvastatin and gemfibrozil in human plasma by reversedphase liquid chromatography. Lat. Am. J. Pharm., v.29, p.1383-1388, 2010 .

KHAN, I.U.; KAUSAR, T.; ASHFAQ, M.; SHARIF. S. Development and validation of liquid chromatographic method for the simultaneous estimation of ezetimibe and lovastatin in human plasma. J. Chil. Chem. Soc., v.55, p.461-464, 2010.

KHAN, I.U.; ASHFAQ, M.; RAZZAQ, S.N.; MARIAM, I. Simultaneous determination of piroxicam and paracetamol in pharmaceutical formulations using stability indicating HPLC method. J. Liq. Chrom. Rel. Technol. V.36, p.1437$1450,2013$.

KWAK, H.W.; D'AMICO, D.J. Determination of dexamethasone sodium phosphate in vitreous by high performance liquid chromatography. Korean J. Ophthalmol, v.9, p.79-83, 1995.

MALLINSON, E.T.; DREAS, J.S.; WILSON, R.T.; HENRY A.C. Determination of dexamethasone in liver and muscle by liquid chromatography and gas chromatography/mass spectrometry. J. Agric. Food Chem., v.43, p.140-145, 1995.

MARONA, H.R.N.; SCHAPOVAL, E.E.S. Performance characteristics of bioassay, UV-Spectrophotometry and high performance liquid chromatographic determination of sparfloxacin in tablets. Braz. J. Pharm. Sci., v.37, p.171175,2001

MARONA, H.R.N.; ZUANAZZI, J.A.S.; SCHAPOVAL, E.E.S. Determination of sparfloxacin and its degradation products by HPLC-PDA. J. Antimicrob. Chemother., v.44, p.301-302, 1999.
MARONA, H.R.N.; SCHAPOVAL. E.E.S. Spectrophotometric determination of sparfloxacin in tablets. J. Antimicrob. Chemother., v.43, p.136-137, 1999.

MODY, V.D.; PANDYA, K.K.; SATIA, M.C.; MODI, I.A.; MODI, R.I.; GANDHI. T.P. High performance thinlayer chromatographic method for the determination of sparfloxacin in human plasma and its use in pharmacokinetic studies. J. Pharm. Biomed. Anal., v.16, p.1289-1294, 1998.

NOH, K.; KWON, K.; JEONG, T.C.; KANG, W. Quantitative determination of sparfloxacin in rat plasma by liquid chromatography/tandem mass spectrometry. J. Biomed. Chrom., v.24, p.1199-1202, 2010.

QUTAB, S.S.; RAZZAQ, S.N.; ASHFAQ, M.; SHUJA, Z.A.; KHAN, I.U. Simple and sensitive LC-UV method for simultaneous analysis of hydrochlorothiazide and candesartan cilexetil in pharmaceutical formulations. Acta Chromatogr., v.19, p.119-129, $2007 \mathrm{a}$.

QUTAB, S.S.; RAZZAQ, S.N.; KHAN, I.U.; ASHFAQ, M.; SHUJA. Z.A. Simultaneous determination of atorvastatin calcium and ezetimibe in pharmaceutical formulations by liquid chromatography. J. Food Drug Anal., v.15, p.139$144,2007 b$.

QUTAB, S.S.; RAZZAQ, S.N.; ASHFAQ, M.; KHAN, I.U.; MUMTAZ. A.M. Simultaneous quantitation of olmesartan medoximil and amlodipine besylate in combined tablets using HPLC. J. Chil. Chem. Soc., v.54, p.234-237, 2009.

RAZZAQ, S.N.; MARIAM, I.; KHAN, I.U.; ASHFAQ, M. Development and validation of liquid chromatographic method for gatifloxacin and ketorolac tromethamine in combined dosage form. J. Liq. Chrom. Rel. Technol., v.35, p.651-661, 2012a.

RAZZAQ, S.N.; ASHFAQ, M.; KHAN, I.U.; MARIAM, I. Development and validation of liquid chromatographic method for moxifloxacin and ketorolac tromethamine in combined dosage form. Quím. Nova, v.35, p.1216-1221, $2012 b$.

RAZZAQ, S.N.; ASHFAQ, M.; KHAN, I.U.; MARIAM, I. Stability indicating HPLC method for the simultaneous determination of ofloxacin and ketorolac tromethamine in pharmaceutical formulations. Anal. Methods, v.4, p.2121$2126,2012 \mathrm{c}$ 
RAZZAQ, S.N.; ASHFAQ, M.; KHAN, I.U.; MARIAM, I. Development and validation of liquid chromatographic method for naproxen and esomeprazole in binary combination. J. Chil. Chem. Soc., v.57, p.1456-1459, 2012 d.

REYNOLDS, J.E.F. Martindale: the extra pharmacopoeia. 36ed. London: Pharmaceutical Press, 2009. p.332, p.1526.

SALGADO, H.R.N.; MORENO, P.R.H.; BRAGA, A.L.; SCHAPOVAL, E.E.S. Photodegradation of sparfloxacin and isolation of its degradation products by preparative HPLC. Rev. Cienc. Farm. Basica Apl., v.26, p.47-54, 2005.

SCHIL, P.N.; CHARLES. B.C. Determination of dexamethasone in plasma of premature neonates using high-performance liquid chromatography. J. Chromatogr. B: Biomed. Appl., v.658, p.189-192, 1994.
SHARIF, S.; KHAN, I.U.; ASHFAQ, M.; IQBAL, M.S.; AHMAD. S. Development and validation of a high performance liquid chromatographic method for the simultaneous determination of potassium clavulanate and cefadroxil in synthetically prepared tablets J. Anal. Chem., v.65, p.1029-1034, 2010.

URBAN, M.C.C.; MAINARDES, R.M.; GREMIAO. M.P.D. Development and validation of HPLC method for analysis of dexamethasone acetate in microemulsions. Braz. J. Pharm.Sci., v.45, p.87-93, 2009.

Received for publication on $17^{\text {th }}$ July 2012 Accepted for publication on $21^{\text {st }}$ February 2013 